\title{
Is AMF inoculation an alternative to maximize the in vitro antibacterial activity of
}

\section{Libidibia ferrea extracts?}

A inoculação com FMA é alternativa para potencializar a atividade antibacteriana in vitro de extratos de Libidibia ferrea?

¿Es la inoculación con HMA una alternativa para potenciar la actividad antibacteriana in vitro de los extractos de Libidibia ferrea?

Received: 12/22/2020 | Reviewed: 12/24/2020 | Accept: 12/30/2020 | Published: 04/09/2021

Emanuela Lima dos Santos

ORCID: https://orcid.org/0000-0003-0136-4730

University of Pernambuco, Brazil

E-mail: emanuela_lima07@hotmail.com

Brena Coutinho Muniz

ORCID: https://orcid.org/0000-0003-2004-2518 University of Pernambuco, Brazil

E-mail: brenamuniz@ hotmail.com.br

Beathriz Godoy Vilela Barbosa

ORCID: https://orcid.org/0000-0002-3291-2421 University of Pernambuco, Brazil E-mail: beathriz.godoy@upe.br

Marcia Maria Camargo de Morais

ORCID: https://orcid.org/0000-0001-5337-1188 University of Pernambuco, Brazil E-mail: marcia.morais@upe.br

Francineyde Alves da Silva

ORCID: https://orcid.org/0000-0003-1501-6868 University of Pernambuco, Brazil

E-mail: francineydes71@gmail.com

Fábio Sérgio Barbosa da Silva

ORCID: https://orcid.org/0000-0001-7798-5408

University of Pernambuco, Brazil

E-mail: fs.barbosa@yahoo.com.br

\begin{abstract}
Arbuscular mycorrhizal fungi (AMF) are known to provide plant species with several benefits, such as an increased production of bioactive compounds. However, it is yet to be defined whether extracts of mycorrhizal plants are more efficient in vitro antibacterial actions when compared to non-mycorrhizal plants. We tested the hypothesis of whether or not, methanolic extracts of Libidibia ferrea fruits, from plants established in the field and inoculated with AMF, have higher antibacterial action when inoculated with Acaulospora longula, Claroideoglomus etunicatum or Gigaspora albida. In addition, native L. ferrea fruits collected from the Caatinga area were also tested. The extracts of $L$. ferrea fruits inoculated with A. longula had higher in vitro antibacterial action in relation to the extracts of fruits from noninoculated plants $(p<0.05)$ thus characterizing the first record of different antibacterial actions of plant extracts due to inoculation with AMF. The extracts of L. ferrea fruits inoculated with A. longula were more efficient in inhibiting growth of Gram-negative bacteria. The zone diameters of inhibition ranged from $2.48 \%$ to $7.56 \%$ larger than the zones of the non-inoculated L. ferrea fruit extracts. The inoculation of L. ferrea with AMF may represent an alternative way of producing fruits with different antibacterial activity.
\end{abstract}

Keywords: Arbuscular mycorrhizal fungi; Bacterial growth; Biocompounds; Caatinga; Fruits; Mycorrhization.

\section{Resumo}

Sabe-se que o uso de fungos micorrízicos arbusculares (FMA) confere benefícios para as espécies vegetais, como aumento na produção de compostos bioativos. Entretanto, não se definiu se extratos de plantas micorrizadas têm atividade antibacteriana in vitro superior àqueles obtidos de vegetais não micorrizados. Foi testada a hipótese de que extratos de frutos de Libidibia ferrea inoculada com FMA possuem maior atividade antibacteriana. Para isso, foram utilizados extratos metanólicos de frutos de L. ferrea, estabelecida em campo e inoculada ou não com Acaulospora longula, Claroideoglomus etunicatum, Gigaspora albida, além daqueles obtidos de frutos de L. ferrea coletados em área da caatinga. Os extratos dos frutos de L. ferrea inoculada com A. longula foram mais eficazes frente a cepas de bactérias Gram-negativas, com halos de inibição que foram de $7.56 \%$ a $2.48 \%$ maiores que halos dos extratos de frutos de $L$. ferrea não inoculada. Para o ensaio de atividade antibacteriana in vitro foram utilizadas as cepas Escherichia coli, 
Escherichia coli, Staphylococcus aureus e Staphylococcus aureus. Os extratos dos frutos de L. ferrea inoculada com A. longula tiveram maior ação antibacteriana in vitro, frente às cepas testadas, em comparação com os extratos de frutos de plantas não inoculadas ( $\mathrm{p}<0.05$ ), caracterizando o primeiro relato da ação antibacteriana diferenciada de extratos vegetais em função da inoculação com FMA. A inoculação de L. ferrea com FMA pode ser alternativa para produção de frutos com ação antibacteriana diferenciada.

Palavras-chave: Biocompostos; Caatinga, Crescimento bacteriano; Frutos; Fungos micorrízicos arbusculares; Micorrização.

\begin{abstract}
Resumen
Se sabe que el uso de hongos micorrízicos arbusculares (HMA) proporciona beneficios para las especies vegetales, como una mayor producción de compuestos bioactivos. Sin embargo, no se ha definido si los extractos de plantas micorrízicas tienen una actividad antibacteriana in vitro superior a los obtenidos a partir de vegetales no micorrízicos. Se probó la hipótesis de que los extractos de los frutos de Libidibia ferrea inoculados con HMA tienen una mayor actividad antibacteriana. Para ello se utilizaron extractos metanólicos de frutos de L. ferrea, establecidos en campo e inoculados o no con Acaulospora longula, Claroideoglomus etunicatum, Gigaspora albida, además de los obtenidos de frutos de $L$. ferrea recolectados en la zona de caatinga. Los extractos de frutos de inoculados con A. longula fueron más efectivos contra cepas de bacterias Gram-negativas, con halos de inhibición que fueron $7.56 \%$ a $2.48 \%$ mayores que los halos de extractos de frutos L. ferrea L. ferrea no inoculado. Se utilizaron cepas de Escherichia coli, Escherichia coli, Staphylococcus aureus y Staphylococcus aureus para el ensayo de actividad antibacteriana in vitro. Los extractos de frutos de L. ferrea inoculados con A. longula tuvieron mayor acción antibacteriana in vitro, en comparación con las cepas ensayadas, en comparación con los extractos de frutos de plantas no inoculadas ( $\mathrm{p}<0.05$ ), caracterizando el primer reporte de la acción. antibacteriano diferenciado de extractos de plantas dependiendo de la inoculación con HMA. La inoculación de L. ferrea con HMA puede ser una alternativa para la producción de frutos con acción antibacteriana diferenciada.
\end{abstract}

Palabras clave: Biocompuestos; Caatinga; Crecimiento bacteriano; Frutos; Hongos micorrízicos arbusculares; Micorrizas.

\title{
1. Introduction
}

As documented in many studies, arbuscular mycorrhizal fungi (AMF) are microorganisms that provide plant species with several benefits (Wu et al., 2016; Amiri, Nikbakht, Rahimmalek, \& Hosseini, 2017; Tavarini et al., 2018). However, only a few papers have recorded whether 'products' with higher mycorrhizal efficiency in plants have a different action, such as mycorrhizal plant extracts.

Some studies reported that the use of AMF inoculation in plants of medicinal interest enhances the production of bioactive compounds (Oliveira, Alves, Silva, \& Silva, 2015; Amiri et al., 2017). This may provide the species with medicinal properties, such as antioxidant (Giovannetti et al., 2012), antitumor (Nakamura et al., 2002), and antimicrobial activities (Silva et al., 2013b).

Some of the tested species are natives to Brazil, such as Anadenanthera colubrina (Vell.) Brenan, Inga vera Willd., Mimosa tenuiflora (Wild.) Poir., and Libidibia ferrea (Mart. ex Tul.) L.P.Queiroz. These studies revealed extracts of mycorrhizal plants with a higher concentration of phenols, tannins, flavonoids and other biomolecules (Pedone-Bonfim et al., 2013; Silva et al., 2014a, 2014b; Lima, Campos, \& Silva, 2015; Santos, Silva, \& Silva, 2017; Silva and Silva, 2017).

Even though the plant organs accumulate more compounds whenever the plants are mycorrhizal, only one study has reported whether mycorrhization with Funneliformis mossae (T.H. Nilcolson \& Gerd.) C. Walker \& Schuessler, in addition to increasing the concentration of essential oils extracted from mycorrhizal Anethum graveolens L., var. Hanák, maximizes the fungicidal effect of these essential oils against Colletotrichum nymphaeae (Pass.) Aa strain CCh32; the fungus which causes anthracnose in strawberries (Karimi et al., 2016).

However, no records have been found in literature about the efficiency of medicinal plant extracts demonstrating a higher concentration of phenolic compounds resulting from mycorrhization. Therefore, the following question arises: Can mycorrhization, in addition to increasing the production of phenolic compounds in medicine plants, also maximize their medicinal actions? 
It is crucial to develop investigations that seek to prove the efficiency of mycorrhizal medicinal plant extracts as alternatives to phytochemical studies associated with AMF inoculation. This is because the focus of the field rather the mycorrhizal efficiency at producing phytochemicals (Lima et al., 2015; Almeida, Sawaya, \& Andrade, 2018) than the efficiency of mycorrhizal plant extracts. The confirmation of this hypothesis could benefit the phytotherapeutic drugs industry in regards to the preparation of the raw-material used in the production chain of more efficient phytotherapeutic drugs as well as to collaborate with health practices who are seeking alternatives for the use of phytotherapeutic drugs associated with traditional medicine (WHO, 2013).

In this context, considering the increasing worldwide number of reports about the emergence of multidrug resistant bacteria (Rice, 2018), one alternative to mitigate this problem could be the development of medicinal plant extracts with efficient antimicrobial activity. Organs of $L$. ferrea have shown antimicrobial activity (Silva et al., 2013a; Araújo et al., 2014; Biasi-Garbin et al., 2016) and the extracts of mycorrhizal plants have increased the production of compounds such as flavonoids, tannins and gallic acid (Silva et al., 2014a, 2014b; Santos et al., 2017). However, it is yet to be confirmed if these extracts could present a higher antibacterial activity than those of non-mycorrhizal plants. Therefore, our aim was to verify the in vitro antibacterial activity of methanolic extracts of $L$. ferrea fruits, from plants inoculated or not with AMF; considering the strains of Grampositive and Gram-negative bacteria resistant or not to antibiotics. We tested the hypothesis that the extracts of L. ferrea fruits from plants inoculated with AMF have higher antibacterial action.

\section{Material and Methods}

We used L. ferrea fruits, mycorrhizal or not, maintained since February 2013, in the Experimental Field of the Laboratory of Mycorrhizal Technology (LTM/UPE), University of Pernambuco, Campus Petrolina (9²3'54.1" S; 40²8'49.0" W). After 32 months of field transplant, fruits were collected and used for the testing of antibacterial activity in laboratory.

\subsection{Field experiment}

For the field experiment, seedlings produced in a greenhouse were inoculated or not with soil inoculum containing 200 spores of each AMF isolate. We used Acaulospora longula Spain \& N.C. Schenck (UFPE 21), Claroideoglomus etunicatum (W. N. Becker \& Gerdemann) C. Walker \& A.Schussler) (UFPE 06) and Gigaspora albida N.C. Schenck \& G.S. Sm. (UFPE 01), granted by the Department of Mycology of the Federal University of Pernambuco. Seedlings without AMF were taken as control. After 225 days, the seedlings were transplanted to the experimental field (Silva et al., 2014a).

In the field, the seedlings were distributed using a spacing of $5 \mathrm{~m} \mathrm{(5 \times 5)}$ apart from each other with irrigation through semi-automatic dripping $\left(8.4 \mathrm{~L} \mathrm{H}_{2} \mathrm{O}\right.$ plant $\left.^{-1} \mathrm{~h}^{-1}\right)$. Before the transplant, each pit $(40 \mathrm{x} 40 \mathrm{x} 40 \mathrm{~cm})$ received five liters of vermicompost and $150 \mathrm{~g}$ of simple superphosphate. The plants were distributed in six blocks containing 16 plants each, totaling 96 plants in the field area. Surrounding the field, we developed a border which consisted of non mycorrhizal L. ferrea plants (Silva et al., 2014b). Two central plants of each portion were used for the analyses.

\subsection{Phytochemical and biochemical characterizations and phosphorus content of $L$. ferrea extract}

After 32 months of transplantation, the fruits were collected, cleaned using cotton and then kiln-dried (Quimis Ltda, Diadema, Brazil) $\left(45^{\circ} \mathrm{C}\right)$. Subsequently, $2 \mathrm{~g}$ of fruits (with peel and seeds) were cut into four pieces $(13.81 \mathrm{~mm}$ in width and $12.29 \mathrm{~mm}$ in length) with garden shears (Agass Ltd, China) and ground in a multiprocessor (Black+Decker ${ }^{\circledR}$, USA) for 90 seconds. The resulting material was macerated in $20 \mathrm{~mL}$ of methanol $(80 \%)$ for 10 days at $20^{\circ} \mathrm{C}$ (Brito, Noronha, França, Brito, $\&$ Prado, 2008). The extracts were gauze-filtered, refiltered in qualitative filter paper, and stored in a freezer $\left(-18^{\circ} \mathrm{C}\right)$. 
Research, Society and Development, v. 10, n. 1, e10010111435, 2021

(CC BY 4.0) | ISSN 2525-3409 | DOI: http://dx.doi.org/10.33448/rsd-v10i1.11435

The methanolic extracts of the fruits were used for the following quantifications: total phenols (Orujei, Shabani, \& Sharifi-Tehrani, 2013), total flavonoids (Araújo, Alencar, Amorim, \& Albuquerque , 2008), total tannins (Monteiro et al., 2006; Orujei et al., 2013), total proanthocyanidins (Queiroz, Morais, \& Nascimento, 2002), total saponins (Vigo, Narita, \& Marques, 2003), antioxidant activity (Rufino et al., 2007, modified) and total soluble carbohydrates (Dubois, Gilles, Hamilton, Rebers, \& Smith, 1956). The phosphorus content was also determined (Santos et al., 2020) (Table 1). 
Table 1. Characterization of the methanolic extracts of Li/'bidibia ferrea fruits (Mart. ex Tul.) L.P.Queiroz inoculated or not with Acaulospora longula, Claroideoglomus etunicatum, Gigaspora albida, and of the methanolic extracts of native Libidibia ferrea fruits (Mart. ex Tul.) L.P. Queiroz collected in a Caatinga area, in Petrolina, PE, Brazil.

\begin{tabular}{|c|c|c|c|c|c|}
\hline \multirow[t]{2}{*}{ Characterization } & \multicolumn{5}{|c|}{ Contents in extracts methanolic } \\
\hline & Control $^{1}$ & A. longula ${ }^{2}$ & C. etunicatum ${ }^{3}$ & G. albida ${ }^{4}$ & Native fruit $^{5}$ \\
\hline Total phenols $\left(\mathrm{mg} \mathrm{g}^{-1}\right)$ & 235.50 & 297.80 & 265.20 & 217.60 & 250.10 \\
\hline Total tannins $\left(\mathrm{mg} \mathrm{g}^{-1}\right)$ & 156.40 & 218.60 & 182.10 & 148.80 & 155.50 \\
\hline Total flavonoids $\left(\mathrm{mg} \mathrm{g}^{-1}\right)$ & 158.60 & 154.60 & 146.40 & 119.60 & 124.22 \\
\hline Total proanthocyanidins $\left(\mathrm{mg} \mathrm{g}^{-1}\right)$ & 12.43 & 10.71 & 11.32 & 10.55 & 4.50 \\
\hline Total saponins $\left(\mathrm{mg} \mathrm{g}^{-1}\right)$ & 5.50 & 4.33 & 3.77 & 4.40 & 4.82 \\
\hline $\mathrm{AAO}\left(\mathrm{mg} \mathrm{g}^{-1}\right.$ of remaining $\left.\mathrm{DPPH}\right)$ & 89.20 & 59.80 & 104.90 & 91.60 & 2.88 \\
\hline Phosphorus content $\left(\mathrm{mg} \mathrm{Kg}^{-1}\right)$ & 375.70 & 203.70 & 452.20 & 524.40 & 656.66 \\
\hline Soluble carbohydrates $\left(\mathrm{mg} \mathrm{g}^{-1}\right)$ & 8.48 & 7.56 & 7.00 & 5.03 & 1.59 \\
\hline
\end{tabular}

$\mathrm{AAO}=$ Antioxidant activity; A. Longula= Acaulospora longula C C. etunicatum= Claroideoglomus etunicatum; G. albida= Gigaspora albida; L. ferrea= Libidibia ferrea; DPPH (2,2 Diphenyl-1picrylhydrazyl). ${ }^{1}$ L. ferrea fruits without inoculation; ${ }^{2}$ L. ferrea fruits inoculated with A. longula; ${ }^{3} L$. ferrea fruits inoculated with $C$. etunicatum; ${ }^{4} L$. ferrea fruits inoculated with $G$. albida; ${ }^{5}$ Native L. ferrea fruits. Source: Authors. 


\subsection{In vitro antibacterial activity tests}

The in vitro antibacterial activity analyses were carried out in the Laboratory of Microbial Resistance (LRM), University of Pernambuco - Campus Santo Amaro.

\subsubsection{Bacterial strains}

The strains Escherichia coli (Migula) Castellani and Chalmers (ATCC ${ }^{\circledR}$ 25922) and Staphylococcus aureus subsp. aureus Rosenbach (ATCC ${ }^{\circledR}$ 25923) as well as two strains of resistant bacteria, the ESBL-producing Escherichia coli (Migula) Castellani and Chalmers (ATCC ${ }^{\circledR}$ 35218) (ESBL- Extended spectrum beta-lactamase) and the MRSA- Staphylococcus aureus subsp. aureus Rosenbach (ATCC ${ }^{\circledR}$ 33591) (MRSA- Methicillin resistant Staphylococcus aureus) were used. The strains were stored in liquid LB (Luria-Bertani) a medium containing $15 \%$ glycerol, (at $-20^{\circ} \mathrm{C}$ ), and reactivated in Agar Mueller-Hinton (Kasvi, Brasil) medium at the moment of use.

\subsubsection{Screening method for antibacterial activity}

Methanolic extracts of $L$. ferrea fruits inoculated with A. longula, C. etunicatum, G. albida, and extracts of L. ferrea fruits without AMF inoculation (control) were used. In addition, collected extracts of native $L$. ferrea fruits, from the Caatinga area ( $9^{\circ} 23^{\prime} 54.1^{\prime \prime} \mathrm{S} ; 40^{\circ} 28^{\prime} 49.0^{\prime}$ W), were tested. A control, constituted only of methanol (80 \%) (Química moderna Ltda, Barueri, Brasil) was also used.

Mueller-Hinton agar (Kasvi, Brasil) plates were inoculated by swabbing a standardized bacterial inoculum, corresponding to 0.5 on the MacFarland (CLSI, 2012) scale. Subsequently, wells with $18 \mathrm{~mm}$ in diameter were made, with sterile apparatus, and given $150 \mu \mathrm{L}$ of methanolic extract from $L$. ferrea fruits, or methanol ( $80 \%)$. The plates were incubated at $37{ }^{\circ} \mathrm{C}$ for $18 \mathrm{~h}$ (CLSI 2018). In order to monitor the method's performance, one well containing $1 \mu \mathrm{g} \mathrm{mL}^{-1}$ ciprofloxacin solution was used as a reference for each plate.

The zones of inhibition which were formed surrounding the wells were measured using digital pachymeter (Lee tools, Ltda) (Araújo et al., 2014, modified). Two measures from each well were taken to generate an average for each sample. This test was conducted in technical triplicate for each sample.

\subsubsection{Minimum inhibitory concentration (MIC)}

The minimum inhibitory concentration was determined by microtritation in Mueller-Hinton broth using microdiluition plates (CLSI, 2012). In the first well of each raw was placed with $200 \mu \mathrm{L}$ of the extract (100 mg mL ${ }^{-1}$ of initial concentration) from inoculated and non-inoculated plants. From the second well, the extract was mixed with $100 \mu \mathrm{L}$ of Mueller-Hinton broth, totaling $200 \mu \mathrm{L}$ per well. Eight dilutions of the extract were made, the concentrations varied between $100 \mathrm{mg} \mathrm{mL}^{-1}$ and 0.78 $\mathrm{mg} \mathrm{mL}{ }^{-1}$, in technical triplicate for each sample. Each well received $5 \mu \mathrm{L}$ standardized inoculum of 0.5 McFarland diluted (1:10, in saline solution), the plants were incubated for 20 to $24 \mathrm{~h}$ at $37^{\circ} \mathrm{C}$.

\subsubsection{Experimental design}

The design for each bacterial strain was completely randomized with six treatments: extracts of $L$. ferrea fruits inoculated with A. longula; extracts of $L$. ferrea fruits inoculated with C. etunicatum; extracts of L. ferrea fruits inoculated with G. albida; extracts of $L$. ferrea fruits without AMF (control) inoculation; extracts of $L$. ferrea fruits collected in a Caatinga area and a control with methanol ( $80 \%)$. 
Research, Society and Development, v. 10, n. 1, e10010111435, 2021

(CC BY 4.0) | ISSN 2525-3409 | DOI: http://dx.doi.org/10.33448/rsd-v10i1.11435

\subsection{Statistical analysis}

The data was subjected to ANOVA and the averages compared by using a Duncan test (5\%) on software Assistat (7.7).

\section{Results}

The methanolic extracts of $L$. ferrea fruits inoculated with A. longula had higher in vitro antibacterial activity when compared to those from non-inoculated plants. This was for all the bacterial strains studied (Table 2).

The zones of inhibition produced by methanolic extracts of $L$. ferrea fruits inoculated with A. longula, regarding to the strains E. coli $\left(\right.$ ATCC $\left.^{\circledR} 25922\right)$, E. coli $\left(\right.$ ATCC $^{\circledR}$ 35218), S. aureus $\left(\right.$ ATCC $^{\circledR} 25923$ ), and S. aureus $\left(\right.$ ATCC $^{\circledR} 33591$ ) were 7.56 $\%, 5.22 \%, 2.74 \%$, and $2.48 \%$ greater, respectively, than the zones produced by methanolic extract from control (Table 2). 


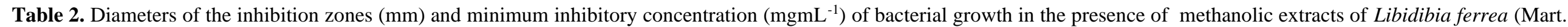
ex Tul.) L.P. Queiroz fruits inoculated or not with AMF, methanolic extracts of native L. ferrea fruits collected in a Caatinga area and $80 \%$ methanol solution

\begin{tabular}{|c|c|c|c|c|c|c|c|c|}
\hline \multirow[t]{3}{*}{ Treatments } & \multicolumn{8}{|c|}{ Bacterial strains } \\
\hline & \multicolumn{2}{|c|}{ E. coli (ATCC-25922) } & \multicolumn{2}{|c|}{ E. coli (ATCC-35218) } & \multicolumn{2}{|c|}{ S. aureus (ATCC-25923) } & \multicolumn{2}{|c|}{ S. aureus (ATCC- 33591) } \\
\hline & $\begin{array}{c}\text { Inhibiton } \\
\text { zone }\end{array}$ & MIC & $\begin{array}{c}\text { Inhibition } \\
\text { zone }\end{array}$ & MIC & $\begin{array}{c}\text { Inhibiton } \\
\text { zone }\end{array}$ & MIC & Inhibition zone & MIC \\
\hline Control & $22.20 \mathrm{~d}$ & $\geq 100$ & $22.40 \mathrm{c}$ & $\geq 100$ & $28.76 \mathrm{~b}$ & 100 & $31.82 \mathrm{~b}$ & 100 \\
\hline A. longula & $23.88 \mathrm{a}$ & $\geq 100$ & $23.57 \mathrm{a}$ & $\geq 100$ & $29.55 \mathrm{a}$ & 100 & $32.63 \mathrm{a}$ & 100 \\
\hline C. etunicatum & $21.80 \mathrm{e}$ & $\geq 100$ & $22.54 \mathrm{~b}$ & $\geq 100$ & $27.71 \mathrm{c}$ & 100 & $32.26 \mathrm{ab}$ & 100 \\
\hline G. albida & $23.41 \mathrm{~b}$ & $\geq 100$ & $21.35 \mathrm{~d}$ & $\geq 100$ & $28.44 \mathrm{~b}$ & 100 & $31.88 \mathrm{~b}$ & 100 \\
\hline Native fruit & $23.22 \mathrm{c}$ & $\geq 100$ & $23.18 \mathrm{a}$ & $\geq 100$ & $27.13 \mathrm{~d}$ & 100 & $31.31 \mathrm{c}$ & 100 \\
\hline Methanol (80\%) & $18.00 \mathrm{f}^{*}$ & - & $18.00 \mathrm{e}^{*}$ & - & $18.00 \mathrm{e}^{*}$ & - & $18.00 \mathrm{~d}^{*}$ & - \\
\hline $\mathrm{CV}(\%)$ & 0.76 & - & 2.00 & - & 1.27 & - & 1.28 & - \\
\hline
\end{tabular}

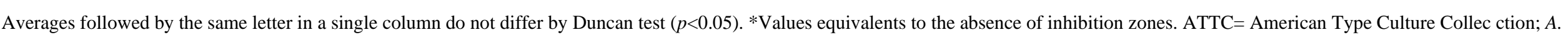

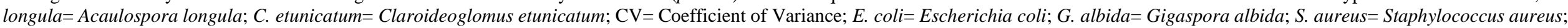
MIC= Minimum Inhibitory Concentration. Source: Authors. 
In the MIC test only the highest concentration $\left(100 \mathrm{mg} \mathrm{mL}^{-1}\right)$ showed bacterial growth inhibition for $S$. aureus (ATCC® 25923) and S. aureus (ATCC® 33591) strains. For other strains, E. coli (ATCC® 25922) and E. coli (ATCC® 35218), bacterial growth was observed in all concentrations (Table 2).

\section{Discussion}

This is the first record of different effects of mycorrhizal $L$. ferrea extracts in regards to the bacteria. This effect was probably due to the increased concentration of phenols $(26.4 \%)$ and tannins $(39.77 \%)$ observed and compared to the methanolic extract of non-inoculated L. ferrea fruits (Table 1). Similar reports have also shown an association of bacterial growth inhibition with the presence of phenols in fruit extracts from plants of Caatinga (Sampaio et al., 2009; Silva et al., 2013a). In addition, the inhibitory effect of tannins on growth of S. aureus-MRSA strains has also been reported (Okuda, 2005; Okuda \& Ito, 2011).

Similarly, regarding the phenolic compounds, Karimi et al. (2016) also reported that essential oils extracted from mycorrhizal A. graveolens with $F$. mosseae had higher action against $C$. nymphaeae than essential oils of non mycorrhizal plants. The authors attributed such a benefit to the contents of the essential oils carvone and limonene.

However, the presence of FMA does not always increase the efficiency of plant extracts in inhibiting bacterial growth (Table 2). The zones of inhibition produced by some of the methanolic extracts of mycorrhizal $L$. ferrea fruits tested against $E$. coli (ATCC ${ }^{\circledR}$ 35218) were similar to those formed by extracts of native L. ferrea fruits collected in the Caatinga region (Table 2) and the MIC test of these strains showed bacterial growth independent of the concentration tested, what did not occurred with Gram-positive strains (S. aureus ATCC® 25923) and S. aureus (ATCC® 33591) which showed growth in the highest concentration (Table 2), this fact, demonstrates the importance of complementary tests to verify the antibacterial activity.

It is likely that, different phytochemical and nutritional profiles of the plant extracts may have interfered in the bacterial growth, such as the phosphorus concentration which is an important nutrient for bacterial growth and has different values in the fruits used in this study according to the AMF inoculated (Table 1). The alterations in the phosphorus concentrations activate, or not, the regulation systems which influence the microorganism growth (Behrendes et al., 2014; Shimizu, 2014). In turn, this may have influenced the bacterial growth regarding the extracts of L. ferrea fruits inoculated with A. longula. In addition, the inhibitory potential of the bacterial growth may vary according to the bacterial species thus giving rise to different efficiencies of the extracts (Conde et al., 2015; Oliveira et al., 2015). As verified in our study (Table 2).

AMF inoculation can be efficient at maximizing the in vitro antibacterial activity of extracts of L. ferrea fruits and represents an alternative to the production of raw materials for the material manufacture of phytotherapeutic drugs based on $L$. ferrea fruits. The inhibition zones produced by the methanolic extracts of L. ferrea fruits inoculated with A. longula varied from 21.35 to $32.63 \mathrm{~mm}$ (Table 2) and were higher than the zones produced by extracts of $L$. ferrea fruits collected in the Caatinga, which varied between 11 and $18.5 \mathrm{~mm}$ (Oliveira et al., 2015; Silva et al., 2013a; Conde et al., 2015).

In general, extracts of $L$. ferrea inoculated with A. longula inhibited both Gram-positive and Gram-negative bacteria (Araújo et al., 2014; Nascimento et al., 2015; Ferreira et al., 2016), as recorded in this study (Table 2). However, it is worth highlighting that the extracts of $L$. ferrea inoculated with A. longula were also efficient in inhibiting the antibiotic resistant strains of both Gram-negative e Gram-positive bacteria (Table 2). 


\section{Conclusion}

Thus, the inoculation of L. ferrea with A. longula can be an alternative to producing fruits with different antibacterial activities thus contributing to the World Health Organization guidelines, which seek to integrate alternative and traditional medicine (WHO, 2013).

Our tests are still in their primary stage with regards to the production chain of raw materials which can be used in the phytotherapeutic drugs industry. Therefore, it is necessary to develop studies to verify the efficiency of different concentrations of methanolic extracts of L. ferrea fruits, in addition to toxicity tests on the extracts of mycorrhizal plants (Braquehais et al., 2016; Santos et al., 2017). Complementary studies should include assessing the synergic effect of extracts of mycorrhizal $L$. ferrea fruits with antibiotics.

\section{Acknowledgments}

The authors would like to thank the FACEPE (Fundação de Amparo à Ciência e Tecnologia do Estado de Pernambuco) for granting the doctorate scholarship (Proc. IBPG-1549-2.03/15), CAPES (Coordenação de Aperfeiçoamento de Pessoal de Nível Superior) and CNPq (Conselho Nacional de Desenvolvimento Científico e Tecnológico) for granting the research productivity scholarship to F.S B. Silva (Proc. 307749/2105-0).

\section{References}

Almeida, C. L., Sawaya, A. C. H. F., \& Andrade, S. A. L. (2018). Mycorrhizal influence on the growth and bioactive compounds composition of two medicinal plants: Mikania glomerata Spreng. and Mikania laevigata Sch. Bip. ex Baker (Asteraceae). Brazilian Journal of Botany, $41,233-240$.

Amiri, R., Nikbakht, A., Rahimmalek, M., \& Hosseini, H. (2017). Variation in the essential oil composition, Antioxidant capacity, and physiological characteristics of Pelargonium graveolens L. inoculated with two species of mycorrhizal fungi under water deficit conditions. Journal of Plant Growth Regulation, 36, 502-515.

Araújo, T. A. S., Alencar, N. L., Amorim, E. L. C., \& Albuquerque, U. P. (2008). A new approach to study medicinal plants with tannnis and flavonoids contentes from the local knowledge. Journal of Ethnopharmacology, 120, 72-80.

Araújo, A. A., Soares, L. A. L., Ferreira, M. R. A., Souza Neto, M. A., Silva, G. R., Araújo Jr, R. F., \& Melo, M. C. N. (2014). Quantification of polyphenols and evaluation of antimicrobial, analgesic and anti-inflammatory activities of aqueous and acetone-water extracts of Libidibia ferrea, Parapiptadenia rigida and Psidium guajava. Journal of Ethnopharmacology, 156, 88-96.

Biasi-Garbin, R. P., Demitto, F. O., Amaral, R. C. R., Ferreira, M. R. A., Soares, L. A., Svidzinski, T. I. E., \& Yamada-Ogatta, S. F. (2016). Antifungal potential of plant species from brazilian caatinga against dermatophytes. Revista do Instituto de Medicina Tropical de São Paulo, 58 : 18.

Braquehais, I. D., Vasconcelos, F. R., Ribeiro, A. R. C., Silva, A. R. A., Franca, M. G. A., Lima, D. R., \& Magalhães, F. E. A. (2016). Estudo preliminar toxicológico, antibacteriano e fitoquímico do extrato etanólico das folhas de Jatropha mollissima (Pohl) Baill. (pinhão-bravo, Euphorbiaceae), coletada no Município de Tauá, Ceará, Nordeste Brasileiro. Revista Brasileira de Plantas Medicinais, 18, 582-587.

Behrends, V., Maharjan, R. P., Ryall, B., Feng, L., Liu, B., Wang, L., \& Ferenci, T. (2014). A metabolic trade-off between phosphate and glucose utilization in Escherichia coli. Molecular BioSystems, 10, 2820-2822.

Brito, H. O., Noronha, E. P., França, L. M., Brito, L. M. O., \& Prado, M. S. (2008). Análise da composição fitoquímica do extrato etanólico das folhas de Annona squamosa (ATA). Revista Brasileira de Farmacognosia, 89, 180-184.

Clinical and Laboratory Standards Institute -CLSI (2012) Methods for Dilution Antimicrobial Susceptibility Tests for Bacteria That Grow Aerobically; Approved Standard. (9th ed.). CLSI document M07-A9. Wayne, PA: Clinical and Laboratory Standards Institute.

Clinical and Laboratory Standards Institute -CLSI (2018). Performance Standards for Antimicrobial Susceptilibity testing. (28th ed.). M100, USA.

Conde, N. C. O., Pereira, M. S. V., Bandeira, M. F. C. L., Venâncio, G. N., Oliveira, G. P., \& Sampaio, F. C. (2015). In vitro antimicrobial activity of plants of the Amazon on oral biofilm microrganisms. Revista Odonto Ciência, 30, 179-183.

Dubois, M., Gilles, K. A., Hamilton, J. K., Rebers, P. A., \& Smith, F. (1956). Colorimetric method for determination of sugars and related substances. Analytical Chemistry, 28, 350-356.

Ferreira, M. R. A., Fernandes, M. T. M., Silva, W. A. V., Bezerra, I. C. F., Souza, T. P., Pimentel, M. F. \& Soares, L. A. L. (2016). Chromatographic and spectrophotometric analysis of phenolic compounds from fruits of Libidibia ferrea Martius. Pharmacognosy Magazine, 12, 285-291.

Giovannetti, M., Avio, L., Barale, R., Ceccarelli, N., Cristofani, R., \& Iezzi, A. (2012). Nutraceutical value and safety of tomato fruits produced by mycorrhizal plants. British Journal of Nutrition, 107, 242-251. 
Karimi, K., Aharia, A. B., Weisany, W., Pertot, I., Vrhovsek, U., \& Arzanlou, M. (2016). Funneliformis mosseae root colonization affects Anethum graveolens essential oil composition and its efficacy against Colletotrichum nymphaeae. Industrial Crops and Products, 90, 126-134.

Lima, C. S., Campos, M. A. S., \& Silva, F. S. B. (2015). Mycorrhizal fungi (AMF) increase the content of biomolecules in leaves of Inga vera Willd. seedlings. Symbiosis, 65, 117-123.

Monteiro, J. M., Albuquerque, U. P., Lins Neto, E. M. F., Araújo, E. L., Albuquerque, M. M., \& Amorim, E. L. C. (2006). The effects of seasonal climate changes in the Caatinga on tannin levels in Myracrodruon urundeuva (Engl.) Fr. All. and Anadenanthera colubrina (Vell.) Brenan. Brazilian Journal of Pharmacognosy, 16, 338-344

Nakamura, E. S., Kurosaki, F., Arisawa, M., Mukainaka, T., Okuda, M., Tokuda, H., \& Pastore Junior, F. et al. (2002). Cancer chemopreventive effects of constituints of Caesalpinia ferrea and related compounds. Cancer Letters, 177, 119-124.

Nascimento, P. L. A., Nascimento, T. C. E. S., Gomes, J. E. G., Silva, M. D. S., Souza, S. A., Silva, T. M. S., \& Moreira, K. A. (2015). Antioxidant and antimicrobial properties of ethanolic extract of Libidibia ferrea pods. Revista Fitos, 9, 161-252.

Oliveira, P. T. F., Alves, G. D., Silva, F. A., \& Silva, F. S. B. (2015). Foliar bioactive compounds in Amburana cearensis (Allemao) A. C. Smith seedlings: Increase of biosynthesis using mycorrhizal technology. Journal of Medicinal Plants Research, 9, $712-718$.

Okuda, T. (2005). Systematics and health effects of chemically distinct tannins in medicinal plants. Phytochemistry, 66, $2012-2031$.

Okuda, T., \& Ito, H. (2011). Tannins of constant structure in medicinal and food plants-Hydrolyzable Tannins and Polyphenols Related to Tannins. Molecules, $16,2191-2217$.

Oliveira, G. P., Souza, T. P., Caetano, S. K., Farias, K. S., Venâncio, G. N., Bandeira, M. F. C. L., \& Conde, N. C. O. (2015). Antimicrobial activity in vitro extrats of the stem bark and fruit of Libidibia ferrea L. against microrganisms of the oral cavity. Revista Fitos, 8, 73-160.

Orujei, Y., Shabani, L., \& Sharifi-Tehrani, M. (2013). Induction of glycyrrhizin and total phenolic compound production in licorice by using arbuscular mycorrhizal fungi. Russian Journal of Plant Physiology, 60, 855-860.

Pedone-Bonfim, M. V. L., Lins, M. A., Coelho, I. R., Santana, A. S., Silva, F. S. B., \& Maia, L. C. (2013). Mycorrhizal technology and phosphorus in the production of primary and secondary metabolites in cebil (Anadenanthera colubrina (Vell.) Brenan) seedlings. Journal of the Science of Food and Agriculture, 93, 1479-84.

Queiroz, C. R., Morais, A. L., \& Nascimento, E. A. (2002). Caracterização dos taninos da aroeira-preta (Myracrodruon urundeuva). Revista Árvore, 26, 485492.

Rice, L. B. (2018). Antimicrobial stewardship and antimicrobial resistance. Medical Clinics of North America, 102, 805-818.

Rufino, M. S. M., Alves, R. E., Brito, E. S., Morais, S. M., Sampaio, C. G., Pérez-Jiménez, J., \& Saura-Calixto, F. D. (2007). Metodologia Científica: determinação da atividade antioxidante total em frutas pela captura do radical livre DPPH. Comunicado Técnico,127, EMBRAPA 1-4

Santos, E. L., Silva, F. A., \& Silva, F. S. B. (2017). Arbuscular mycorrhizal fungi increase the phenolic compounds concentration in the bark of the stem of Libidibia ferrea in field conditions. The Open Microbiology Journal, 11, 283-291.

Santos, E. L., Silva, W. A. V., Ferreira, M. R. A., Soares, L. A., Sampaio, E. V. S. B., Silva F. A, \& Silva, F. S. B. (2020). Acaulospora longula increases the content of phenolic compounds and antioxidant activity in fruits of Libidibia ferrea. The Open Microbiology Journal, 14, 132-139.

Sampaio, F. C., Pereira, M. S. V., Dias, C. S., Costa, V. C., Conde, N. C. O., \& Buzala, M. A. R. (2009). In vitro antimicrobial activity of Caesalpinia ferrea Martius fruits against oral pathogens. Journal of Ethnopharmacology, 124, 289-294.

Shimizu, K. (2014). Regulation systems of bacteria such as Escherichia coli in response to nutrient limitation and environmental stresses. Metabolites, 4, 1-35.

Silva, L. C. N., Sandes, J. M., Paiva, M. M., Araújo, J. M., Figueiredo, R. C. B. Q., Silva, M. V., \& Correia, M. T. S. (2013a). Anti-Staphylococcus aureus action of three Caatinga fruits evaluated by electron microscopy. Natural Product Research, 27, 1492-6.

Silva, L. C. N., Miranda, R. C. M., Gomes, E. B., Macedo, A. J., Araújo, J. M., Figueiredo, R. C. B. Q., \& Correia, M. T. S. (2013b), Evaluation of combinatory effects of Anadenanthera colubrina, Libidibia ferrea and Pityrocarpa moniliformis fruits extracts and erythromycin against Staphylococcus aureus. Journal of Medicinal Plants Research, 7, 2358-2364.

Silva, F. A., Silva, F. S. B., \& Maia, L. C. (2014a). Biotechnical application of arbuscular mycorrhizal fungi used in the production of foliar biomolecules in ironwood seedlings [Libidibia ferrea (Mart. Ex Tul.) L. P. Queiroz var. ferrea. Journal of Medicinal Plants Research, 8, 814-819.

Silva, F. A., Ferreira, M. R. A., Soares, L. A. L., Sampaio, E. V. S. B., Silva, F. S. B., \& Maia, L. C. (2014b). Arbuscular mycorrhizal fungi increase acid gallic production in leaves of field grown Libidibia ferrea (Mart. Ex Tul.) L. P. Queiroz. Journal of Medicinal Plants Research, 8, $1110-1115$.

Silva, F. A., \& Silva, F. S. B. (2017). Is the application of arbuscular mycorrhizal fungi an alternative to increase foliar phenolic compounds in seedlings of Mimosa tenuiflora (Wild.) Poir., Mimosoideae?. Brazilian Journal of Botany, 40, 361-365.

Tavarini, S., Passera, B., Martini, A., Avio, L., Sbrana, C., Giovannetti, M., \& Angelini, L. G. (2018). Plant growth, steviol glycosides and nutrient uptake as affected by arbuscular mycorrhizal fungi and phosphorous fertilization in Stevia rebaudiana Bert. Industrial Crops and Products, $111,899-907$.

Vigo, C. L. S., Narita, E., \& Marques, L. C. (2003). Validação da metodologia de quantificação espectrofotométrica das saponinas de Pfaffia glomerata (Spreng.) Pedersen - Amaranthaceae. Revista Brasileira de Farmacognosia, 13, 46-49. 
Research, Society and Development, v. 10, n. 1, e10010111435, 2021 (CC BY 4.0) | ISSN 2525-3409 | DOI: http://dx.doi.org/10.33448/rsd-v10i1.11435

WHO. (2013). WHO Traticional Medicine Strategy: 2014-2023. WHO Library Catoguing-in-Publication Data

Wu, S., Zhang, X., Chen, B., Wu, Z., Li, T., Hu, Y., \& Wang, Y. (2016). Chromium immobilization by extraradical mycelium of arbuscular mycorrhiza contributes to plant chromium tolerance. Environmental and Experimental Botany, 122, 10-18. 